Jeffrey S. Librett

\title{
A touch of separation- toward an ethics of anxiety in the age of the global contagion
}

Jeffrey S. Librett

\begin{abstract}
I examine the relation between anxiety and the COVID-19 pandemic. For context, I begin by sketching the rise of anxiety as a theme from the $19^{\text {th }}$ century to the post-World War II era, as a mood of the individual in a world without absolutes. Then, I characterize the current moment as the age of the anxiety of the global contagion. Next, I examine the most general effects of the COVID-19 pandemic on the individual ego, as simultaneous radical separation from and connection with others. I proceed to juxtapose this situation with Freud's anxiety theory, which likewise involves simultaneous separation and connection. The social ego today thus appears, from a Freudian perspective, as in an exacerbated anxiety-state. I claim that this exacerbation helps us understand more clearly Freud's anxiety theory, and vice versa. I then consider where this anxiety takes place, and so I examine the Freudian "site" of anxiety-the ego. This examination clarifies two aspects of Freud's ego-theory: both the sense in which the Freudian ego is (post)modern, and the sense in which Freud's linkage of anxiety with the ego is not occasional, but constitutive. That is, the ego is the site of anxiety, in that anxiety characterizes the ego as such, because the ego is a (post) modern liminal structure. I suggest in conclusion that the affirmation and acceptance of anxiety as a fundamental experience of the ego, and of the psyche more generally, constitutes an ethical imperative for psychoanalysis in general, and especially in the contemporary age of the global contagion.
\end{abstract}

\section{Psychoanalysis of a pandemic?}

While I chose the topic of "Anxiety in Perspective(s)" as the theme of our first Special Issue long before the COVID-19 crisis materialized, unfortunately the theme could not have been a better match for the current moment. It feels necessary to say something in this Issue about anxiety in relation to the situation, due to both the gravity of the crisis and the manifest importance of anxiety as a widespread response-although in other contexts one might also examine mourning, depression, rage, denial, or other psychic reactions. Rather than provide these remarks in the Introduction to this first Special Issue of Metalepsis, and thereby-in terms of the structure of the volume--slow down or obstruct the readers' access to the texts themselves, I have decided to insert them after the other main articles-nachträglich, as Freud would say--as a kind of Editorial Afterword or Supplement. Do not the best anticipations come afterwards?

By discussing the connection between anxiety and the pandemic context, I am not claiming that we can already say on the basis of reliable empirical research to what precise 
extent anxiety has been exacerbated broadly by the COVID-19 crisis. $^{1}$ Rather, I will develop a more narrowly self-limiting, yet theoretical perspective, stopping short of empirical work. My main claim is that the effects of the crisis concerning the situation of the ego in its world embody and instantiate the types of experience that psychoanalysisat least in Freud-determines as both the occasions of anxiety in general and the enduring conditions of the ego's existence in its world. Which is to suggest, as I will, that the ego's position is constitutively an anxious one. Our situation during the pandemic exacerbates the anxiety of the (modern--and postmodern) ego in general, and thereby highlights the sense in which such anxiety is endemic to this ego, especially in the current historical epoch (which I will try briefly to circumscribe and contextualize against a larger historical background). Freudian theory helps us understand this exacerbation and its baseline, as in turn this theory is brought into focus by the current situation. ${ }^{2}$ My concern, then, is to show how the situation of the ego in the current crisis both sheds light on, and is illuminated in turn by, the Freudian understanding of anxiety in relation to the ego in general. I conclude with a very brief reflection on the implications of this mutual clarification for a psychoanalytic ethics.

\section{The Age of the Global Contagion}

To begin by setting the COVID-19 crisis in a very broad historical context, let us recall that, in terms of intellectual history (taken here as an index of human experiences more generally in each period), anxiety is a pervasive phenomenon in "modern" societies, at least in the West. In a general and often fairly explicit way, anxiety has functioned in an important strand of intellectual and cultural history as a fundamental mood-indeed, as the distinctive affective trait of the human being--ever since the late Romantic period,

\footnotetext{
${ }^{1}$ See, for example, Perreault 2020. But more material documenting the manifest heightening of anxiety under COVID-19 appears every week.

2 The empirical study of the phenomena of anxiety during the COVID-19 pandemic has to occur elsewhere, of course-with the caveat that, from a psychoanalytic perspective, the conscious ego cannot without further ado be in a position to authorize a testimony on the presence or absence of anxiety within itself, or on the potentially quantifiable intensity of its anxiety. This is the case despite the fact that, as I explore below, the ego is for Freud "the actual site of anxiety," since "actual site" does not mean "unquestionable judge of its own experience." Such a consideration means that a relatively straightforward survey methodology will, in this question, remain problematic. But the methodology of an empirical verification of anxiety is not our concern here.
} 
when (as the German philosopher Odo Marquard [1968, 2004] has spelled out) the aestheticization of nature as a secular absolute, nature's status as an ideal, beautiful/sublime safe space, began to lose its plausibility. ${ }^{3}$ Anxiety supervenes as the only certainty-that of uncertainty and constitutive endangerment, or fragility-when even the secular faiths in reason (Enlightenment), then in the spiritual appreciation of nature as harmonious aesthetic ideal (Romanticism), have lost the aura of validity, i.e. when they have ceased to be believable. More concretely, anxiety becomes a prominently explicit theme in philosophy in 1844 when Kierkegaard publishes The Concept of Anxiety (Kierkegaard 1980), which builds in new ways on the work of his teacher Schelling's lectures on freedom, reflections Schelling extended in his Ages of the World project (Schelling 1987 and 2000).4 Secularization and political modernization--the French Revolution establishing the cut-off through the action of the guillotine--leave the individual without absolute foundations (no God, no King, no substantial Paternity). She has nothing left then with which to mediate her relationship with the world, linking her to it while preserving her separateness and individuality. This combined linkage and separation had previously been accomplished by a common faith for pre-modern subjects, who in addition could imagine themselves as organic elements in a meaningful sociopolitical order that was in consonance with that faith and its God. They were connected with a world but remained separate, supported by an eternal structure, indeed held in existence by God himself. Once both Enlightenment "reason" (which eroded religion and tried to replace it) and then Romantic "feeling" (which in turn eroded rationality and tried to replace it) have come and gone as substitutes for faith in a patriarchal theopolitical order, the modern self is left to its own devices to both connect with, and separate its inwardness from, the realities of the world as best it can. The anxious condition of this modern self-which keeps disappearing into and away from the

\footnotetext{
3 If the aesthetics of the Romantic "sublime" could certainly involve terror and similar emotions, the telos of the experience was always conceived in idealist terms as the transcendence of the material realm of the body: the discovery, as Immanuel Kant put it, of the "supersensuous destiny" of the human being. This transcendence comes to seem questionable as Romanticism becomes conventionalized and the materiality of social life in industrializing Europe comes to seem increasingly insurmountable. Edgar Allan Poe, for example, would be a limit-figure here. 4 On the initial philosophical thematization of anxiety in the work of Friedrich Schelling, see Librett 2021 (forthcoming). On the relationship between anxiety in Schelling and Kierkegaard, see Hennigfeld and Stewart 2003.
} 
world--is registered by the rise of a discourse on anxiety in the $19^{\text {th }}$ century. 5 And Freud's theory of the "ego" is an apt formulation of this modern self-a point to which I'll return below.

Fast forwarding now: in the late $20^{\text {th }}$ century, after left- and right-wing totalitarianism have repeated in caricature the opposed tendencies of Enlightenment rationalism and Romantic irrationalism during World War II, the late- or post-romantic situation replays itself, displaced in manifold ways of course, as post-modernity, in an age that questions both rationality and naïve sentiment, and that is skeptical of all ideologies in general and the grand narratives they support. Accordingly, W. H. Auden famously characterized the post-World War II conjuncture as The Age of Anxiety in his book-length poem of that name from $1948 .{ }^{6}$ Doubtless in part because we are still at the far end of the post-World War II period (as we witness only now the fading of the "Boomer" generation's domination of the society and the public sphere), it is not surprising that anxiety is still being invoked, as if it were self-evident, as the defining mood-trait or affective essence of the current period. And indeed, we can expect the problem of anxiety to extend well beyond the post-World War II period, in ever new forms, even as it preceded that period by more than a century.

The COVID-19 pandemic--taking place within a moment of global neoauthoritarian backlash that exploits a xenophobic response to cultural globalization while operating in terms of global digital (dis)information warfare--has brought this anxious modern and postmodern "foundation" to the surface in a manner that, although we should have anticipated it, has taken us largely by surprise. Uncertain cultural, political, and epistemic values coincide here with a new-old threat from nature. And the multiple vulnerabilities complicate each other to the point of seeming at times hard to distinguish.

\footnotetext{
5 When Hegel expressed his concern, in the Aesthetics (given as lectures repeatedly in the 1820s) that the uncontrolled subjectivism of romantic irony led to an anxious or anguished sense of endless, empty longing occupying a formalistic wasteland, he was touching upon a phenomenon what would have a long future, to which his proposed solutions, however, would not turn out to be enduringly persuasive, as the critiques of Hegelianism, beginning precisely with the late Schelling and the young Kierkegaard, have proven. Hegel 1970, vol. 13, 93-99; vol. 14, 220-244. ${ }^{6}$ See Auden 2011. The phrase, "Age of Anxiety," is still very much alive. For example, it is the title of a 2012 film by Scott Harper, a book from 1996 edited by Sarah Dunant and Roy Porter, an article in The New Republic by Talia Lavin from February 26, 2019, a forthcoming novel by Pete Townshend, etc. Despite the rise to prominence of depression as a competitor for the status of an illness characteristic of our society as a whole, anxiety persists as a socially significant form of suffering and ostensible general mood seventy years after the appearance of Auden's poem.
} 
We are working overtime now, it seems, to generate the Angstbereitschaft-the "anxietypreparedness"-that, Freud says, the traumatized try to create retrospectively, and retroactively-nachträglich--in order to anticipate the disruption that has already occurred, as well as those that are coming. 7 Anxiety appears anew the mood of the day, albeit not without being combated by diverse means, including rational and scientific ones, but often simply by denial and various forms of magical thinking. Our modern and postmodern anxiety traditions extend themselves now more narrowly within an age of what we can call "the global contagion."

To clarify, before moving on to examine the position of the ego in this age: the phrase "the age of the global contagion" should be understood here to name or englobe not just the COVID-19 pandemic or other potential literal viruses, but also the contagion of the "global" itself, or (cultural) globalization as a generalized cultural contagion, as well as the virality of digital information flows. While the mutual cultural infections cannot be stopped, and constitute a "good" form of contagion, or at the very least a neutral or uncertain value (depending in part on what the human future will make of them), the literal viral contagion is to be combatted, of course, and the digital contagion is to be controlled to the degree possible by something like "truth." Thus dictates, at any rate, the drive to self-preservation. But what is essential here is their combined anxiety-inducing character.

On the question of the intercultural contagion: like laughter or yawning, culture is simply contagious. We catch it from our neighbors, and imitation (they say) is the highest form of flattery. All cultures, by communicating with each other, through digital communication technologies, travel, and migration, appropriate and disappropriate each other (ultimately rendering vain any attempt-however justified-to contain "cultural appropriation"), entering into each other and disrupting each other's pure, or internal, self-reproductive processes. When cultural globalization becomes an acknowledged phenomenon (patent in the US perhaps since 9/11, after which it was impossible to pretend that the Muslim world, for example, lay outside "our own"), even as it's been

7 See, for example, Beyond the Pleasure Principle (Freud 1964, vol. 18, 31-3; Freud 1969-79, vol. 3, 241-43). Note that the term, "Angstbereitschaft" can mean both "preparedness for anxiety" and "anxious as preparedness," a temporal ambiguity rarely noted in Freud's phrasing here. 
growing for a very long time, quantity flips over into quality (in the Hegelian phrase), and cultural interpenetration becomes ineluctable. ${ }^{8}$ One no longer believes that it can be prevented (except if one indulges in naïve forms of denial, which of course are also rampant). 9 The cultures can henceforth no longer be separated from each other, but neither can they be unified, if only because the unity of each is disarticulated by its interactions with the manifold others. None henceforth seems capable of achieving or, at any rate, maintaining exclusive domination. ${ }^{10}$ The cultures are coming together precisely in coming apart, in all senses: (not) reproducing each other in (not) reproducing themselves. This is not entirely reassuring for the ego and its sociocultural identity.

Further, our age is one of global contagion on the level of information flows. Information-including false or misleading information, both intentional and unintentional-spreads uncontrollably through the global digital space, with positive and negative effects, peaceable and polemical or warring tendencies. The task of controlling the negative effects of false or destructive information-virality is like the task of controlling any literal "virus," insofar as information uses its recipients to reproduce itself and to displace their own self-reproduction qua rational consciousness and selfconsciousness. The current, uncontrollable character of information flows makes us all vulnerable to being infected by demonstrably false narratives, even as narratives closer to the truth can likewise be mobilized against them.

\footnotetext{
${ }^{8}$ For psychoanalytically oriented essays on the significance of cultural globalization for the situation of the "subject," see Savoir 2016; Librett 2020.

${ }_{9}$ The anxious-making character of the Corona virus, its uncanniness, is exacerbated by the fact that the immune system sometimes actually causes the organism to die by attacking itself in attempting to close itself off against the invading virus, a phenomenon of auto-immunity that is hauntingly similar to the xenophobic walling-off of the culture against other cultures, a walling-off that threatens to be fatal to the culture that closes itself off. The virus, which in itself has nothing to do with cultural communication, nonetheless reminds us of it in this respect too. Perhaps all communities, like all egos, have a tendency to attack the others on the outside, to push them out, and in so doing to attack aspects of themselves they can find in these others, as is argued in terms of a "general logic of autoimmunization" by Derrida 2002, 80 .

${ }^{10}$ It is striking to the point of intolerable that, in the horrific and socially symptomatic murder of George Floyd, the condensation of the racist disavowal of cultural globalization coincides with the literal strangling of the other human being, which appears here as the homicidal externalization or projection of the suffocating effects with which anxiety (in this case xenophobic) is etymologically tied, and also as a denial of the other's "spirit" along with his very life. Moreover, these realities are overdetermined, in the bad dream of the present, by the often suffocating effects of COVID-19 itself. Protesters bearing signs with the words "I can't breathe" have put their lives on the line to object to such racist xenophobia, underlining the humanity of those whose humanity is being denied, by linking them with the vulnerability of the human as such.
} 
In sum, we live in an age of global contagion in the literal sense, as well as concerning intercultural communication and digital information flows. ${ }^{11}$ In this perspective, the COVID-19 crisis is just one particular exacerbation of the current epochal situation, which brings its global conditions usefully into relief. The newest stage, in the ongoing age of anxiety since early post-Romantic modernity, is the epoch of the anxiety of global contagion.

\section{Separation and Touch in the Moment of COVID-19}

So how does anxiety present itself in the moment of COVID-19, as an epitome of the age of global contagion? And then: how does psychoanalysis shed light on this presentation, and vice versa? To approach these questions, we need to consider first how the virus has changed our relationship to the world around us.

Both the danger represented by the COVID-19 situation-including the virtual collapse and ongoing transformations in the aforementioned forms of social order and meaning-and the manner in which we attempt to evade this danger--manifestly take on two principal and complementary forms. On the one hand, both the danger and the safe haven from the danger present themselves as residing in complete isolation, as embodied both in being-alone-with-mortal illness and in the (a)social modalities and signifiers of quarantine, shelter-in-place imperatives, social distancing, and mask-wearing. All of the latter represent responses to the threat of death itself, the essential and radical solitude of which however resembles these responses as forms of aloneness, and which is dramatically exacerbated, in the case of those who are dying in hospitals, by the fact that they are compelled to die in the absence of their relatives and friends. We realize we are alone (with a new danger), then we isolate or separate ourselves to hide from the absolute isolation or separation that is death. Solitude, aloneness, and separation are therefore manifestly radicalized not just as forms of succor but as forms of endangerment in the age

\footnotetext{
${ }^{11}$ Humanly caused climate change is a phenomenon that combines natural danger with the dangers of culture (including cultural clashes that remain unresolved) and the dangers of misinformation-flows, and in this sense it belongs at the very center of danger in the age of global contagion, and of its anxieties.
} 
of the COVID-19 pandemic, which to some extent explains the force of the desire to "reopen" the society and economy at all costs. ${ }^{12}$

On the other hand, precisely the opposite tendency is also exacerbated-we are revealed on a global scale to be connected as never before, and inextricably bound up with the totality of the human race: we cannot not currently be touched by each other. And the connectedness represents both the danger and the solution to the danger. The othersclose and far-are with us, inside us, as they have at no time before appeared to be with such undeniable palpability, at least in our lifetimes. We need to avoid our connectedness because it means the spread of infection, and yet we have to try to connect-to cooperate in mutual isolation, for example-in order to avoid connection qua contagion.

And finally, these two dimensions enter into each other: our togetherness (e.g. in the fact that we can infect each other, that our very breath is dangerous to others) separates us-forcing us to avoid each other, to fear each other, to see in the others the possibility of our death itself-and our separation makes us touch each other, both in the sense that we need to coordinate with others to remain separate, and in the sense that we are moved, "touched" emotionally or metaphorically, by the separateness of the others. We are "touched," in all senses, by our separations, and we touch each other in these very separations, for it is precisely the separation that we share.13 Fearing and seekingambivalently--both separation and touch, we also find in each extreme its otherseparation in touch, and touch in separation-ambiguously: the social uncanny in the age of contagion. ${ }^{14}$

How, then, is the apparent anxiety, as a response to the pandemic--or rather the effect of the global contagion, which is that separation and connection appear uncannily intertwined, as well as ambiguously safe and endangering--illuminated by the conceptualization of anxiety in the psychoanalytic tradition? Or in the converse

\footnotetext{
12 Melanie Klein's last essay, “The Sense of Loneliness,” (Klein 1975), which reads as an essay on anxiety, expresses well the sense in which solitude entails the experience of self-fragmentation.

13 See Nancy 1991 for his beautiful and rigorous articulation of a notion of community rooted in the sharing of radical solitude. For a critical reading of Nancy, see Derrida 2005, where the themes of solitude and touch are explored in terms of phenomenology and its limits.

14 Given more space, it would be possible to carry out an analogous analysis of the situation of the ego in relation to both cultural contagion and information contagion. In these two relations also the ego both seeks its safety and flees its endangerment not only through self-isolation from "external" cultural influences (or information from "without") but also by getting in touch with, and opening itself to, such influences (and information).
} 
formulation: how do psychoanalytic determinations of the notion of anxiety resonate with the organizing polarities of the global contagion's subjective effects?

\section{Anxiety of Separation and Touch in Freud}

As is well known, in his second theory of anxiety, once he tires of trying to determine how repressed libido transforms itself into anxiety (his first, incomplete theory), and decides instead that anxiety precedes and precipitates repression (rather than the other way around), Freud argues primarily that anxiety is a response to a separation that recalls traumatic and personality-constitutive separations, the whole series of separations from birth to weaning to castration to separation from the parents, the superego, and life itself. ${ }^{15}$ As is less evident in Freud's later writings on anxiety, however, anxiety can also appear as a response to connection, that is, to the possibility of touch, or contact. ${ }^{16}$ The main context of this thought of an anxiety of touch appears, in Totem and Taboo, as the discussion of "taboo" itself, along with its "neurotic" equivalent, the obsessional sensibility:

It is precisely this neutral and intermediate meaning [between "sacred" and "unclean"]-'demonic' or 'what may not be touched' [das nicht berührt werden darf]-that is appropriately expressed by the word 'taboo,' since it stresses a characteristic which remains common for all time both to what is sacred and to

\footnotetext{
15 See Inhibitions, Symptoms, and Anxiety (Freud 1964, vol. 20, 77-178; Freud 1969-79, vol. 6, 227-310); and "Anxiety and Instinctual Life" (Freud 1964, vol. 22, 81-111; Freud 1969-79, vol. 1, 517-43).

${ }^{16}$ It is important to note but easy to miss that in Freud's works there is extensive analysis of anxiety as related to touching, in addition to the consideration of anxiety as related to separation (or precisely not being able to touch). Somewhat enigmatically, however, although this analysis appears in Totem and Taboo, and to some extent also in Group Psychology and the Analysis of the Ego, it does not reappear except marginally-in an "isolated" situationduring the discussion of obsessional isolation as one manifestation of the typically obsessional anxiety about touch, when Freud discusses anxiety as a general theme in Inhibitions, Symptoms, and Anxiety (Freud 1964. Vol. 20, 121-2; Freud 1969-79, vol. 6, 265). Nor does it appear in the Introductory Lectures on "Anxiety" and "Anxiety and Instinctual Life," although Freud does touch upon the "anxiety of touch" (Berührungsangst) once fleetingly in the Introductory Lecture 20 on "The Human Sexual Life," once again as a symptom of obsessive-compulsive neurosis (Freud 1964, vol. 16, 309; Freud 1969-79, vol. 1, 306). When Berührungsangst falls away from the larger mature anxiety discussions, the theme of anxiety as concerned with separation becomes problematically simplified, not only because it appears as if anxiety concerned separation alone, but also because it becomes easier to overlook the senses in which separation and connection are always implicitly intertwined, albeit not necessarily happily or harmoniously, i.e. the sense in which separation is anxious-making when it involves separation from oneself (as that with which one remains connected), and that connection is anxious-making when it involves connection with the other (as what one has no connection with), or again: when connection involves self-separation or self-disarticulation as self-difference.
} 
what is unclean: the dread of contact with it [die Scheu vor seiner Berührung] (Freud 1964, vol. 13, 25; Freud 1969-79, vol. 9, 317).

And concerning the obsessional formation:

the principal prohibition. . . is like in taboo against touching [Berührung], hence the name, 'touching phobia' [Berührungsangst] or délire du toucher. . . Anything that directs the patient's thoughts to the forbidden object, anything that brings him into intellectual contact with it, is just as much prohibited as direct physical contact .... Obsessional patients behave as though the 'impossible' persons and things were carriers of a dangerous infection [Träger einer gefährlichen Ansteckung] liable to be spread by contact on to everything in their neighborhood. I have already drawn attention to the same characteristic capacity for contagion [Ansteckungsfähigkeit] and transference [Übertragung] in my description of taboo. We know, too, that anyone who violates a taboo by coming into contact [Berührung] with something that is taboo becomes taboo himself and that then no one may come into contact with him (Freud 1964, vol. 13, 27; Freud 1969-79, vol. 9, 319-20).

In sum, anxiety can constitute equally a response to separation or to contact.

By a further turn of the screw, however, these two aspects of anxiety surreptitiously involve each other. Separation requires an enduring connection with what one has separated from, and so contains also some aspect of self-separation. For example, if as an infant one is anxious about being separated from the mother, the anxiety is conditioned on one's pre-articulate sense that this mother is (a part of) oneself-that one is separating from oneself, insofar as one has a "oneself" at this stage. If one didn't sense that the mother was essential to oneself, one wouldn't be upset about her absence. Or again: if one were not partially identified with the phallus, one would not be rendered anxious by the idea of castration. Separation thus does not simply put an end to the connection it nonetheless breaks off. To separate from something is to enter into a mediated relationship with it, a relationship mediated at the very least by its absence or lack. Indeed, one could not sense a separation from something with which one did not remain connected. 
And in turn, there can be no connection without some separateness. Touching the other, we discover not just our connection with them but also our separation. Even more importantly, this separation can appear as the separation not just from the other whom we touch, but also from ourselves: losing ourselves (at least in part) in what we touch, we separate from ourselves (i.e. from the ones who are doing the touching). Indeed, when Freud asks himself what is behind the anxiety of touch that appears in taboo, he determines that it ultimately concerns the death-drive, both in the others and in ourselves, i.e. the instance of division, separation, and negativity as such. ${ }^{17}$

In touching, we get in touch also with separation, as in separation we remain, in part, in touch with what we precisely lack of ourselves. ${ }^{18}$ When we experience an anxiety of touch and/or separation, this is because the separation-touch-maybe even more than any determinate thing or object-involves some kind of danger, and an experience of helplessness. What is in danger of being suspended or undone by the touch of separation or the separation of touch?

\section{Anxiety and the "I"-the (Post)Modern Ego as Limit}

Evidently, it is the "I"-the ego-for according to Freud's (second) metapsychological topography, anxiety is situated "in" or "at" the ego. As he repeatedly states: "the ego is indeed the actual site of anxiety" ["das Ich ist ja die eigentliche Angststätte"]. ${ }^{19}$ If anxiety is a disruptive separation-touch, then why does it take place in or at the ego? Or why does it occur to the ego? This has to do with the fact that the ego or "I" is the very site of separations and connections. Indeed, the "I" is perhaps little more or other than that, since Freud defines it as the endlessly self-displacing border-lines where reality and id, id

\footnotetext{
17 See the third section of "Taboo and Emotional Ambivalence," chapter II of Totem and Taboo, especially the last part of this section, part c, "The Taboo upon the Dead" (Freud 1964, vol. 13, 35-64, especially 51-64; Freud 1960-79, vol. 9, 327-54; especially 342-54).

18 Perhaps Lacan means to evoke something of this uncanny and ambivalent combination of continuity and discontinuity with what signifies equally death and salvation when he employs the double negative to characterize anxiety as "not without object." See Lacan 2014, 130ff.

19 The claim appears at least in "The Ego and the Id" (1923), "Inhibitions, Symptoms, and Anxiety" (1926), and

"Anxiety and Instinctual Life" (1933) (Freud 1964, vol. 19, 57; vol. 20, 140; vol. 22, 85; Freud 1969-79, vol. 3, 323; vol. 6, 280; and vol. 1, 520). In the late lecture, Freud replaces "actual" (eigentliche) with "sole" (alleinige). The ego appears there also implicitly as "alone" (allein), in a solitude no other can replace, even as it remains, qua ego, a multiply divided border or limit. I omit here the further commentary that would be possible concerning the word of affirmation-"ja" for "indeed" or "of course"-that Freud attaches to the proposition in "The Ego and the Id."
} 
and superego, superego and reality touch upon, impinge upon, and separate from each other. ${ }^{20}$ No wonder the ego is so stressed out! Its feuding closest relatives give it no peace. Its job as mediator is an endless, thankless task. Not only must it bring together, but it must also separate, and furthermore it must bring together and separate synthesis and separation. Overworked and underpaid, the ego labors on, and as such it is the "site" of anxiety. And this is, as I indicated above, consistent with the position of the modern (and, I am suggesting, also the postmodern) conscious self in a secularized and politically modernized world. But in what exact sense is the ego in Freud "the actual site of anxiety"? It is important that we look into this, because it helps us see how Freud's circumscription of the ego does justice to the situation of the ego in the modern world, especially in the sense of post-Romantic modernity, including this modernity's post-modernist extension and its current form as the age of contagion.

Freud's German renders a certain uncertainty of the ego, its certain uncertainty about the site of its own position, very precisely through the subtle implications of the words he uses here-"the ego is the actual site of anxiety"--which are however-oddlynever remarked upon, and which I would like to explicate, if a bit of philology may be permitted here, in approaching my conclusion. First, the term for "actual" here"eigentlich"-means also the "proper," and is also often best translated as "authentic" (for example in Martin Heidegger's work) or as "literal," as in the expression "eigentliche Bedeutung" or "literal meaning." But these connotations of propriety, authenticity, and literalness are hardly appropriate as characterizations of any psychic instance within the Freudian topography of the psyche. Since ego, id, and superego are inseparable, how can one of these psychic instances alone be the "proper" site of some experience per se? ${ }^{21}$ Are not the other instances always also involved? And does not the ego begin to lose some sense of its own contours precisely in an experience such as that of anxiety?

To support these doubts, the implications of propriety, authenticity, and literalness in the adjective "eigentlich" are counterbalanced and contested-effectively ironized--by

\footnotetext{
${ }^{20}$ See, most especially, "The Ego and the Id."

${ }^{21}$ My analysis of this Freudian saying on anxiety as situated in the ego is influenced, albeit not caused, by the extensive analysis of the concepts of the proper, the authentic, the literal, and the liminal in the writings of Jacques Derrida (1974, 1978, 1982, 1987). For his extended reading of Freud, especially on the death-drive, and his critical reading of Lacan, against the background of the philosophical tradition, see Derrida 1987.
} 
the precariousness of identity of the term Freud uses for "site" here, "Stätte," as a representative of the ego. To be sure, this latter term does mean "site" or "place." Derived from an Indo-European root for "standing," it is related to English words like "stasis" and "static," as well as "stead," not only in words like "homestead" but also "instead," for which there are direct German equivalents: “anstatt" or simply "statt." So a "Stätte" is certainly a place, but what is in that place can always be represented by (and potentially confused with) something placed there in its stead. Its steadiness is unsteady, its static character ekstatic. For what is found in a place can always be the usurper of that place, as for example Martin Luther had noticed--much to his chagrin, outrage, and indignation--was the case with the Pope as the "placeholder" for the "place" of God, a placeholder whose interpretations of God replaced God himself. ${ }^{22}$ The placeholder-Statthalter-can always replace, without our noticing it, what properly belongs in that place, which is henceforth displaced. In Freudian terms: the id or the superego can always assert itself in the place of the ego, and the place of the ego overlaps with those of id, superego, and reality.

Hence, if the proper, authentic, and literal site of anxiety is the place where the ego is, this is only because the ego is, as such, a displaceable and always already displaced site, and because anxiety appears "there" where it encounters the fact that its proper, authentic and literal site is indeterminable, because it borders on three others--id, superego, and reality-but these others continually impinge upon it, as it impinges upon them, each losing itself in the others as it separates from them. The word "Stätte," then, is perfectly chosen for the concept here, since the "site"-Stätte--of anxiety is the site of an unstable

\footnotetext{
22 In "The Freedom of a Christian," Martin Luther calls the Pope a "Statthalter Gottes"-a representative or placeholder of God, and plays on the meaning of "holding a place" to suggest that the Pope has displaced God. "Siehe, wie ungleich sind Christus und seine Statthalter, obgleich sie doch alle wollen seine Statthalter sein und ich fürwahr fürcht, sie seien allzuwahrhaftig seine Statthalter. Denn ein Statthalter ist in Abwesenheit seines Herrn ein Statthalter" (Luther, 122). "Look how dissimilar are Christ and his representatives/placeholders, although they all want to be his place-holders, and indeed I fear that they are all too truly his placeholders. For a placeholder is a placeholder in the absence of his lord." I am by no means suggesting that Luther was able to master the logic of the hermeneutic or subjective "place" he begins to reveal here. Nor am I concerned, in my own argumentation, with any religion, unless it be the religion of the sovereign ego. Rather, my point is simply to note that historical events as large as the Reformation can have been significantly determined by such apparently small concerns as the problem of the self-displacing character of the "place" or "stead." For the self-conscious use of this expression, "Statthalter," as "representative," in a secularized modernist context, see Theodor Adorno's essay on the modern poet Paul Valéry, and on art in the age of the "blind isolation" (blinden Vereinzelung) of the modern individual, "Der Artist als Statthalter" (translated somewhat imperfectly as "The Artist as Deputy" in Shierry Weber Nicholsen's English edition), in Adorno 1974, 1991.
} 
ego: in anxiety, one does not exactly know where one is at, and specifically in relation to reality, the drives, the superego injunctions, and hence one's so-called identity itself. ${ }^{23}$

Appropriately, when Freud says that "the ego is the authentic, actual, or literal site of anxiety," he is not so much making the more limited claim that the ego is where anxiety shows up whenever it appears, but rather making the more extreme claim that the ego is, as such, anxious. For only this understanding of the utterance does justice to Freud's views on both anxiety and the ego. The ego is anxious: it "wants to" separate and connect, and it "is" the separation and connection it also lacks, but it is "afraid" of both, or "hates" them, and out of this ambivalence, it constitutes a fantasy of seduction, or self-assurance through the approval and assent of the Other.

One way in which the fantasy that one's social ego is whole can fail is through the loss of the leader-figure, since the leader is an Other who approves and protects. We are undergoing this failure in the public domain today, without perhaps quite coming to terms with its implications. According to Group Psychology and the Analysis of the Ego (Chapter V), when the leader is lost, the group dissolves in panic, because the cohesion of the group is predicated on the sharing, by all members of the group, of the leader as their common ego-ideal (Freud 1964, vol. 18, 95-99; 1969-79, vol. 9, 90-93). The leader qua common ego-ideal enables individuals to connect into a group while maintaining the knowledge of their separateness and differentiation. At least, such is Freud's general conception. In the current US situation, given the COVID-19 pandemic, the political leadership residing in the Executive branch is absent, at least from the standpoint of a traditional conception of reason, due to Trump's manifest abdication of his responsibility and his apparent reliance on magical thinking. Whereas the discourse of science would evidently be the most appropriate leader in this case-i.e. the leader of the political leader-here the political leader turns violently against the rational-scientific principles of his own possible leadership, insisting that he can lead without them, which is to say that he can lead anarchically, or through the chaotic and arbitrary whims of his ever-changing will, or id.

23 In anxiety one is "dizzy"-one has "vertigo"-as the philosophical tradition has it, from Friedrich Schelling (1987, 256) to Søren Kierkegaard (1980, 61). 
For the one side, the spectacle of this loss of leadership itself exacerbates the dissolution of social unity that preceded the COVID-19 pandemic. Here, too, we are joined together in our coming apart. For the supporters of the Trump regime, on the other side, it is scientific rationality (along with the rational politics of equality) that denies the presence of the human free will in the person of the leader (in turn racialized as white, nationalized as American, etc.). From this side, the (president as) leader is not abdicating but endangered. Hence, for this side, too, panic threatens to ensue. From both political extremes, then, one version of the leader-concretely individual or abstractly scientific and principled, irrational or rational-is seen as endangered by the other.

This is not to establish an equivalency of political positions, since the notion of rational leadership includes the necessity of reflection on its limits, which is not the case for the belief in an irrational leadership that is embraced by the right. The notion of rational leadership, which is in principle finite, implies also a necessary reckoning with the anxiety and objective uncertainty that the limits of rational leadership entail. But it is nonetheless important to see that from both left and right, some form of leadership appears as on the verge of collapse. From the social media to the streets, we are seeing the results of the current government's simultaneous abdication of leadership and violent reassertion of blind authority, and of the general sense of a virtual void in the center. In this situation, we cannot connect with each other through a common leader, so we dissolve into factional, conflictual panic (often enough losing our heads), nor can we separate from each other neatly because each dissolves also inwardly in this situation: we feel bound up with each other, including our enemies, in a deeply alienating and, even more, terror-inducing fragmentation. Panic constitutes the paradoxically social dissolution of the social, as Freud notes, and is in this sense the collective counterpart to anxiety, as an individual dissolution of the individual into helplessness in which the ego finds itself lost.

\section{Anxiety in the Age of the Global Contagion-a Question of Ethics}

We can see, then, that the interplay between separation and connection (or contact, or touch) that is characteristic of the predicament of "global contagion" matches rather 
closely the interplay between separation and connection that is at the core of the psychoanalytic conceptualization of anxiety and panic in Freud. In this sense, perhaps Freud's general theory of anxiety and his remarks on panic help us understand more clearly some of the specific anxiety and social disorder occasioned by the COVID-19 crisis and more broadly by the global contagion and its broad disavowal by our current regime. And in turn, the ambivalent oscillations between the movement toward isolation and the movement toward connection characteristic of the response to COVID-19 shed a clarifying light on the Freudian psychoanalytic construal of anxiety. The global contagion exacerbates (and so reveals anew) the structural anxiety of the ego by rendering extreme and explicit the uncanny tension of differentiated identity between the poles of separation and touch.

To the degree that the ego is (at) the unstable and conflict-ridden border between drives and social reality, drives and superego-injunctions, and superego-injunctions and social reality, the danger of, and desire for, separation or touch concern all of these instances: drives, reality, and superego. They affect the "I" (their constantly selfdisplacing border) everywhere it verges on one of these instances, with which it must and must not become one, or harmonize. Hypervigilance is thus the name-one name--of the ego's game. - What's to do?

The purview of psychoanalysis does not, of course, extend to the solution of the ego's dilemmas. It can, however, begin to know, and help the ego (whose contours are never simple nor assured) and so the subject or psyche as such know always something more about the ego's situation, its "dependencies" (Abhängigkeiten), as Freud calls them, the heteronomy that overdetermines its autonomy. To experience to the fullest extent the anxiety and indeed objective uncertainty of its own position--extended as it is over an abyss like a tightrope between fusion and separation--instead of denying that position, is a good place to start. ${ }^{24}$ Thus an analysis begins (again and again) in the encounter with the failure of the seductions of the ego, and the initiation of an ethics of anxiety's

\footnotetext{
24 The allusion is to Nietzsche 1988, in whose Thus spake Zarathustra, the eponymous hero says: "Humankind is a rope stretched between the animal and the overman-a rope over an abyss" (38). The metaphor is extended into a conceit, like a rope, across Nietzsche's text. As with animal and overman in Nietzsche, so in psychoanalysis the tension between fusional attachment and radical separation remains in force all across the lifespan. The abyss of disappearance remains, too, a dependable companion condition.
} 
assumption, the first steps toward its emancipatory dispersion. And even beyond the strictly clinical domain, analysis is called upon to serve and to support, among other things, the assumption of anxiety, since the alternative is its repression and denial. In the age of global contagion, this assumption-acknowledgement, taking-on, welcoming, and working-through--is more important than ever.

(C)2021 Jeffrey S. Librett jlibrett@uoregon.edu

\section{References}

Adorno, Theodor. Noten zur Literatur. Suhrkamp Verlag, 1974.

---. Notes to Literature. Transl. Shierry Weber Nicholsen. Columbia UP, 1991. 2 vols.

Auden, W.H. The Age of Anxiety: a Baroque Eclogue. Ed. Alan Jacobs. Princeton, 2011.

Derrida, Jacques. Margins of Philosophy. Trans. Alan Bass. University of Chicago P, 1982.

---. Of Grammatology. Trans. Gayatri Chakravorty Spivak. Johns Hopkins UP, 1974.

---. On Touching-Jean-Luc Nancy. Trans. Christine Irizarry. Stanford UP, 2005.

---. The Post Card: from Socrates to Freud and Beyond. Trans. Alan Bass. University of Chicago P, 1987.

---. Truth in Painting. Transl. Geoff Bennington and Ian McLeod. University of Chicago P, 1987.

---. Writing and Difference. Trans. Alan Bass. University of Chicago P, 1978.

Freud, Sigmund, Studienausgabe. Ed. Alexander Mitscherlich et al. Fischer Verlag, 1969-79. 12 vols.

---. The Standard Edition of the Complete Psychological Works of Sigmund Freud. Trans. James Strachey. Hogarth Press, 1964. 24 vols.

Hegel, G.W.F. Vorlesungen über die Ästhetik. Theorie Werkausgabe, vols. 13-15. Suhrkamp Verlag, 1970. 20 vols.

Hennigfeld, Jochem, and Jon Stewart. Ed. Kierkegaard und Schelling: Freiheit, Angst und Wirklichkeit. De Gruyter, 2003. 
Kierkegaard, Søren. The Concept of Anxiety: a Simple, Psychologically Orienting Deliberation on the Dogmatic Issue of Hereditary Sin. Ed. Reidar Thome and Albert B. Anderson. Princeton UP, 1980.

Klein, Melanie. Envy and Gratitude and Other Works 1946-1963. Free Press, 1975.

Lacan, Jacques. Anxiety. The Seminar of Jacques Lacan, Book X. Ed. Jacques-Alain Miller. Transl. A. R. Price. Polity, 2014.

Librett, Jeffrey S. "From the Pantheism Panic to Modern Anxiety: Friedrich Schelling's Invention of the Philosophy of Angst." Forthcoming in: The Palgrave Handbook of German Romantic Philosophy. Ed. Elizabeth Millán Brusslan. Palgrave, 2021.

---. "The Subject in the Age of World-Formation (Mondialisation): Advances in Lacanian Theory from the Québec Group." Innovations in Psychoanalysis: Originality, Development, Progress. Ed. Aner Govrin and Jon Mills. Routledge, 2020.

Luther, Martin. "Von der Freiheit eines Christenmenschen." An den christlichen Adel deutscher Nation, Von der Freiheit eines Christenmenschen, Sendbrief vom Dolmetschen. Ed.Ernst Kähler. Reclam, 1962.

Marquard, Odo. "Several Connections between Aesthetics and Therapeutics in Nineteenth Century Philosophy," in The New Schelling. Ed. Judith Norman and Alistair Welchman. Continuum, 2004, 13-29.

---. "Zur Bedeutung der Theorie des Unbewussten für eine Theorie der nicht mehr schönen Kunst," in Die nicht mehr schönen Künste: Grenzphänomene des Ästhetischen. Ed. H. R. Jauß. Wilhelm Fink Verlag, 1968, 375-92.

Nancy, Jean-Luc. The Inoperative Community. U of Minnesota P, 1991.

Nietzsche, Friedrich. Also sprach Zarathustra. Kritische Studienausgabe. Vol. 4. Ed. Giorgio Colli and Mazzino Montinari. De Gruyter, 1988.

Perrault, Daniel. "New Study Finds Rates of Anxiety and Depression Have Tripled During the COVID-19 Pandemic.” https://kwwl.com/2020/07/24/new-study-finds-rates-of-anxiety-and-depressionhave-tripled-during-the-covid-19-pandemic/. Accessed on July 27, 2020.

Savoir: Psychanalyse et Analyse Culturelle. Mondialisation, défis pour l'humain. Québec: GIFRIC, 2016.

Schelling, F. W. J. "Philosophical Investigations in the Essence of Human Freedom and Related Matters." Trans. Priscilla Hayden Roy. In Philosophy of German Idealism. Ed. Ernst Behler. Continuum, 1987, 217-84.

---. The Ages of the World. Trans. Jason M. Wirth. SUNY, 2000. 